\title{
The Impact of Community Perspectives, Religion, Financial Situation and Laws on the Families' Decision to Offer Fostering or Seeking Guardianship to Children in Jordan
}

\author{
Mijad Al-Dalqamouni \\ Prof. Mohammad Shehada \\ Talal Abu-Ghazaleh University College for Innovation \\ Amman 11192, Jordan
}

\begin{abstract}
This research intended to study the "impact of community perspective, religion, financial situation and laws on the families' decision to offer fostering or seek guardianship to children in Jordan". A Questionnaire was used, as a tool, for collecting information. It was distributed it to Mashrek International School employees, the English School employees, and TAGUCI Colleagues, on a sample of (423). The valid questionnaires were (137). A statistical analysis using Statistical Package for Social Sciences (SPSS) were used to find out the impact of the Independent Variable (impact of community perspective, religion, financial situation and laws) on the dependent variable (families' decision to offer fostering or seeking guardianship to children in Jordan), and the conclusion support that impact.
\end{abstract}

Keywords: Community Perspective, Religion, Financial Situation, Fostering, Guardianship, Orphans, Adoption.

\section{Introduction\& Research Problem:}

Adoption was practiced commonly in past civilizations. It was known as transferring children from their parents to other parents for several reasons: political, inheritance, future marriages and care. Adoption system existed in Babylon, ancient Egyptian, Roman and Greek civilizations. Diseases and wars were the main reasons that these ancient civilizations stated to practice adoption, as many children where left parentless, while the infertility was not related to adoption at that time. A Canadian friend told us that her sister who lives in Canada with her husband and two kids, have decided to adopt an orphan. This made us question ourselves if we would ever think to do such a thing. Then many other questions came to our minds:

- Will we do it?

- Will ourspouses approve it?

- Will our community accept it?

- How does Religion deal with it?

- What does the Jordanian Law say about it?

Objectives:

Our objectives in writing this research is to:

1. Identify and analyze the factors that affect the families' decision to offer fostering or seek guardianship to a child in Jordan.

2. Emphasize the differences between the religious laws and civil laws in regards to the adoption.

3. Providing recommendations to the Ministry of Social Development (MSD) of the importance of increasing the awareness of the community of the adoption substitutes.

\section{Significance:}

Due to wars in some Arabcountries, many parents passed away and many families suffered from bad financial situations that made them unable to protect and support their children. The Jordanian laws does not allow adoption. We believe this research paperis significant, as it will help the community understand that there are other legal actions that can be done to help children in need without being adopted.

\section{Research Hypothesis:}

Ho: Community perspective, religion, financial situation and laws have no impact on families' decision to offer fostering or seek guardianship to children in Jordan at $(\alpha=0.05)$.

$\mathrm{Ho}_{1}$ : Community Perspective has no impact on the families' decision to offer fostering to children in Jordan at $(\alpha=0.05)$. 
$\mathrm{Ho}_{2}$ : Religion has no impact on families' decision to offer fostering to children in Jordan at $(\alpha=0.05)$.

$\mathrm{Ho}_{3}$ : Financial Situation has no impact on the families' decision to offer fostering to children in Jordan at $(\alpha=0.05)$.

$\mathrm{Ho}_{4}$ : Laws has no impact on the families' decision to offer fostering to children in Jordan at $(\alpha=0.05)$.

$\mathrm{Ho}_{5}$ : Community Perspective has no impact on the families' decision to seek guardianship to children in Jordan at $(\alpha=0.05)$.

Ho$_{6}$ : Religion has no impact on the families' decision to seek guardianship to children in Jordan at $(\alpha=0.05)$.

$\mathrm{Ho}_{7}$ : Financial Situation has no impact on the families' decision to seek guardianship to children in Jordan at $(\alpha=0.05)$.

Ho⿱ : Laws has no impact on the families' decision to seek guardianship to children in Jordan at $(\alpha=0.05)$.

Hog: There are no differences between community perspective, religion, financial situation and laws, and the families' decision to offer fostering or seek guardianship to children in Jordan when it comes to demographic and functional variables (Age, Gender, Religion, Level of Education, Monthly Income, and Marital Status) at $(\alpha=0.05)$.

Independent Variables

Community Perspective, Religion,

Financial Situation and Laws
Model:

Figure (1)

Dependent Variables

Families' decision to offer Fostering

or Seek Guardianship to Children
- Community Perspective

- Religion

- Financial Situation

- Laws

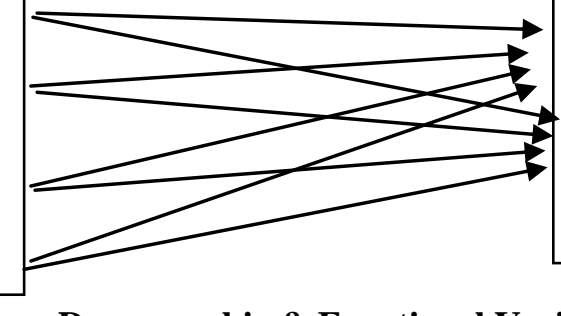

- Offer Child Fostering

- Seek Child Guardianship

\section{Demographic \& Functional Variables}

- Age

- Gender

- Religion

- Level of Education

- Monthly Income

- Marital Status

\section{Literature Review}

\section{Introduction:}

“An orphan is defined by UNAIDS as a child under 15 years of age who has lost his mother ('maternal orphan') or both parents ('double orphan'). It is also generally accepted that the loss of the father would also classify the child as an orphan (UNICEF/UNAIDS, 1999).

The first thing that occurs to peoples' minds when hearing the word ('Adoption') is ('Orphans'), while adoption in language means "Taking something as your own" (Vocabulary.com).

The legal term ('Adoption') means: The legal actions that are taken by a family to forest a child that is not related to any of the parents by blood in order to create a parent-child relationship where the child is entitled to all privileges of the nature child, including the name and the inheritance (Vocabulary.com). 
This definition is still subject to different aspects in different countries. Moreover, it can differ in the same country according to the religion. In India for example, the adoption acts extend only for Hindus families, while personal Indian law of Muslims and Christians does not recognize complete adoption. Both Muslims and Christians of India can take the child in guardianship ('Kafala') only.

\section{The Definition of Guardianship (Kafala) in Islam:}

Guardianship ('Kafala') represents the acceptable adoption model in Islam, as it preserves the blood ties between the biological parents and the child. Islam defines Guardianship - when related to Orphans "The commitment to voluntarily taking care of a minor who is not one's genetic child in the case of an orphan, where the child does not become a true child of the "adoptive" parents" (Bargach, 2002). In Guardianship, the orphan does not carry the same name of the adoptive father but keeps the biological name. In Addition,he/she cannot inheritanything from the adoptive parents.Adoption and Guardianship are similar in regards to raising and taking care of an orphan. In both situations, the adoptive parents are accepting to hold social and financial responsibilities of the orphan. Nevertheless, the legal and religion aspects are what makes them different. Although both actions are encouraged in all religions, different laws and social aspects in some countries consider it as taboo (Figueras, 2015).

Quran has mentioned orphans in different locations; it emphasized the importance and benefits of raising them. That is what Yusra Gomaa, an American lawyer who heads the Muslim Adoption Network explained: "Adoption is not forbidden in Islam. What Islam forbids is stripping away a child's sense of his own biological lineage and biological rights" (Fisher, 2015).

\section{The History of Adoption:}

Adoption in ancient civilizations did not consider the child's best interest, as it was not limited to children only. For example, some Roman emperors adopted adult males to secure an heir. Octavius called Augustus, once he became an emperor, the adopted heir of Julius Caesar (Adkins 1998). This phenomenon was so popular in Rome because of the lack of natural heirs. Most of the Roman emperors were adopted, only few were related by blood to their predecessor. "Adoption of adult men was a convenient recourse for childless aristocrats and for emperors in need of successors" (Hornblower, 2014).

While Romans practiced adoption for political reasons, the Mesopotamians did it because of the high number of orphans or abandoned children in ancient Mesopotamia. The ancient Mesopotamians developed laws in order to equally protect the rights of the adopters and the adoptees especially that, unlike Romans who adopted adults, the Mesopotamians adopted newborn babies. Childless couples adopted orphans in order to give them protection and family, which is similar to today's reasons of adoption. The laws also allowed couples with an already established family to adopt children.

The motivations for adoption varied in the ancient civilizations; people adopted children to get a successor to work in the family workshop, to teach the adoptee a craft, to support the adopter financially, or just to take care of an old-aged adopter. These motives were never in the best of the adoptee. It was not until recently when adoption laws started to focus on the interests of children.

In 1851, the Massachusetts Adoption of children Act became the first adoption law to protect the interest of the child. Because of the Civil War in America, 250,000 orphans were sent tothe Orphans Trains all around American States, Mexico and Canada, where all families in those areas that were interested in adopting an orphan, just waited at the train station to choose a child (Grossman, 2018).

In 1989, The United Nations extended human rights more fully to children than any other legal document. The United Nations Convention on the Rights of the Child inspired many international laws and was signed by 192 countries. This Convention stated in Article (21) that adoption laws should ensure the best interests of the child (UNICEF, 2007). According to UNICIF, an estimated 153 Million children worldwide were orphans.

\section{*Adoption in Different Religions:}

Religious law includes ethical and moral codes taught by religious traditions and customs. Examples include Christian Canon Law, Islamic Sharia, Jewish Halakha, and Hindu Law.

"Religious law emanates from the sacred texts of religious traditions and in most cases purports to cover all aspects of life as a seamless part of devotional obligations to a transcendent, imminent, or deep philosophical reality, either personal or cosmological" (Raisch, 2017).

\section{*Adoption Laws in Islam:}

Islam strongly encourage the care of orphans and vulnerable children. Quran and Sunnah emphasized on the importance of raising and protecting orphans. 
Accordingly, Muslims have ethical and religious responsibilities towards orphans. Although Islamic Law forbids adoption, it highly encourages Guardianship ('Kafala'), as it preserves the child's identity and lineage.Some Islamic countries with large Muslim populations, argued that the Quran does not prohibit adoption claiming that Quran and Sunnah prioritized the wellbeing of the orphans.

In India, Sudan, and Tanzania, different laws regulate adoption and Kafala for non-Muslim than for Muslim children, while another Muslim-majority countries, such as Algeria, and Morocco, regulations governing foreign adoption have been modified to allow for, under certain conditions, transfer of guardianship ('Kafala') of the child to Muslim parents. In the five Muslim-majority countries of Somalia, Indonesia, Malaysia, Tunisia, and Turkey, adoption is legal.

\section{*Adoption Laws in Christianity:}

The Bible placed a big emphasis on orphans although it does not command parents to consider adoption as an acceptable way to raise a family; it includes several verses that represents examples of raising orphans, in addition other verses mention caring for orphans. No prohibition against adoption in Christian Law even if a couple have natural born child (Yeats, 2006).

Therefore, Christians are allowed to legally adopt an orphan where this orphan gets all of the biological child rights including name and inheritance.

Christians, who live in Muslim countries, where laws are driven by the religion (Sharia), have to follow these laws.

\section{*Adoption Laws in Judaism:}

According to Talmud, all Jews, who are physiologically capable of procreating, are obliged by law to sire at least two children. Talmud stresses highly on individuals who raise children, and declares that one who rears an orphan in his own home, even if one already have children of his own is considered as if he has given birth to that child. However, "rearing" of non-biological child in the Jewish Religion is equivalent of foster care rather than adoption, as legal adoption does not exist in Jewish law (Pollack, et al, 2004).

According to the Jewish law, adopted (fostered) children are not considered biological children, which means that they do not inherit the foster father, nor hold his name. If a Jew adopted (fostered) a non-Jewish child, the child will undergo conversion to Judaism, and will not be considered Jewish until he/she reach the age of legal majority (twelve years old for girls, and thirteen for boys). Until then, the child retains the right to renounce the conversion, noticing that this must be done immediately upon reaching the age of legal majority. Otherwise, the conversion will be confirmed.

\section{Guardianship in Jordanian Law:}

The Ministry of Social Development (MSD) and the Family Directorate represent the Authority that supervise the twenty Orphans Care Centers located in different provinces around the Kingdom of Jordan (Mosd.gov.jo)

Since the Jordanian Civil Law is based on the Islamic religion (Sharia), the MSD considers all Jordanian children under its care as abandoned, whether they are born out of wedlock, or the parents are unknown.

According to the Jordanian Laws, the following requirements must be met in order for any couple to obtain a guardianship of a child (Guardianship Instructions 2013):

- The applicants must be a Muslim.

- Married for five years at least.

- Medically certified as infertile.

- Have proof of his financial ability to support the child.

- The legal guardian must wait a minimum of two years before seeking guardianship for another child from the same gender.

In regards to the requirement related to the child, MSD may grant legal guardianship for a child of any age, as long as the child is healthy with no medical conditions or special needs and eligible for guardianship. Research Methodology:

\section{Nature of Research\&Study Population :}

The nature of this research is descriptive and analytical. The descriptive research design was used to explore the impact of community perspectives, religion, financial situation and laws on the families' decision to offer fostering or seeking guardianship to orphans in Jordan.

We chose this research design because we were interested in learning more about the families' decisions to offer fostering or seeking guardianship to orphans in Jordan. Data for the research was collected by using statements of a questionnaire that was distributed to members of three institutions: Mashrek Int'1 School, The New English School and TAGUCI MBA Students. Teachers and graduate students were chosen to fill up the questionnaires. 
The questionnaire was distributed to people from the Jordanian community that work in international schools, and students who are perusing their higher education.

The population of this study is 637. A convenient sample for this study consisted of 423teachers and graduate students. The valid questionnaires we got back were 137. Statistical Package for Social Sciences (SPSS) was used to analyze the collected data by identifying and locating the different variables involved.

\section{Sources of Information:}

The information gathered in this paper is categorized mainly as secondary sources and primary ones. The secondary information was gathered from journals, pamphlets, brochures, books, and searchengines. Primary sources were gathered from distributing a questionnaire that was designed and articulated by a group of specialists in the field of health care to answer the paragraphs of the questionnaire.

The following table shows the population of the study and the questionnaires distributed.

Table (1):

Questionnaire Distribution

\begin{tabular}{|c|c|c|c|c|}
\hline Institution & Population & $\begin{array}{c}\text { No. of } \\
\text { questionnaires } \\
\text { Distributed }\end{array}$ & $\begin{array}{c}\text { No. of } \\
\text { questionnaires } \\
\text { got back }\end{array}$ & $\begin{array}{c}\text { No. of } \\
\text { questionnaires } \\
\text { Rejected }\end{array}$ \\
\hline Mashrek International School & 400 & 263 & 71 & 0 \\
\hline The New English School & 200 & 123 & 44 & 0 \\
\hline TAGUCI MBA Students & 37 & 37 & 22 & 0 \\
\hline Total & $\mathbf{6 3 7}$ & $\mathbf{4 2 3}$ & $\mathbf{1 3 7}$ & $\mathbf{0}$ \\
\hline
\end{tabular}

Reliability and Validity:

\section{Reliability:}

"The reliability of a measure is an indication of the stability and consistency with which the instrument measure the concept and help assess the "goodness" of a measure". (Sekaran \& Bougie, 2010: 161-3).

The integrin consistency reliability is a test of consistency of respondents' answers to all items in a measure. The most popular test of integrin consistency reliability is cronbach's Alpha. (Ibid: 162). Sekaran.

Alpha values are shown in table (2). The range of these values is (0-63--0-92) which indicate the higher the coefficients, the better the measuring instrument.

Table (2)

Cronbach alpha values

\begin{tabular}{|l|c|}
\hline \multicolumn{1}{|c|}{ Variables } & Variables \\
\hline Community Perspective & 0.63 \\
\hline Religion & 0.81 \\
\hline Financial Situation & 0.75 \\
\hline Laws & 0.77 \\
\hline Fostering & 0.90 \\
\hline Guardianship & 0.92 \\
\hline Total & $\mathbf{0 . 7 8}$ \\
\hline
\end{tabular}

Validity:

Measures derived from the questionnaire are reliable because they provide stable and reliable responses. In this paper, Cronbach's Alpha factor was $>70 \%$ and this shows valid and reliable results. Likert Scale 1= Strongly Disagree 2= Disagree 3=Neutral 4=Agree 5=Strongly Agree was used to analyze answers.

\section{Scope:}

The study was carried out in some selected international schools in Amman/Jordan. These Schools areMashrek International School, the English School, and TAGUCI University. The unit of analysis are the teachers in these schools. Most teachers in these schools have a good knowledge about the laws and system related to fostering and guardianships of orphans..

\section{Limitations:}

Lack of previous research studies on the topic. Fostering Laws in Jordan were established in 2013;therefore, limited relevant research studies were available on this subject. The sample for this study was not responding very well because of the time limitation. 


\section{Statistical Analysis:}

\section{Demographics variables}

137areparticipated and filled up the questionnaire fully. Majority are females 111 (81.02\%) and 26 (18.98) males. 115 $(90.5 \%)$, their age groups are nearly equal except for age group 51 years and above with only $22(9.95 \%)$. Nearly two thirds of the sample hold a bachelor degree. 40 (29.2\%) have a monthly income of less than $500 \mathrm{JD}$. A little more than half are married $78(56.9 \%)$.

\section{Gender}

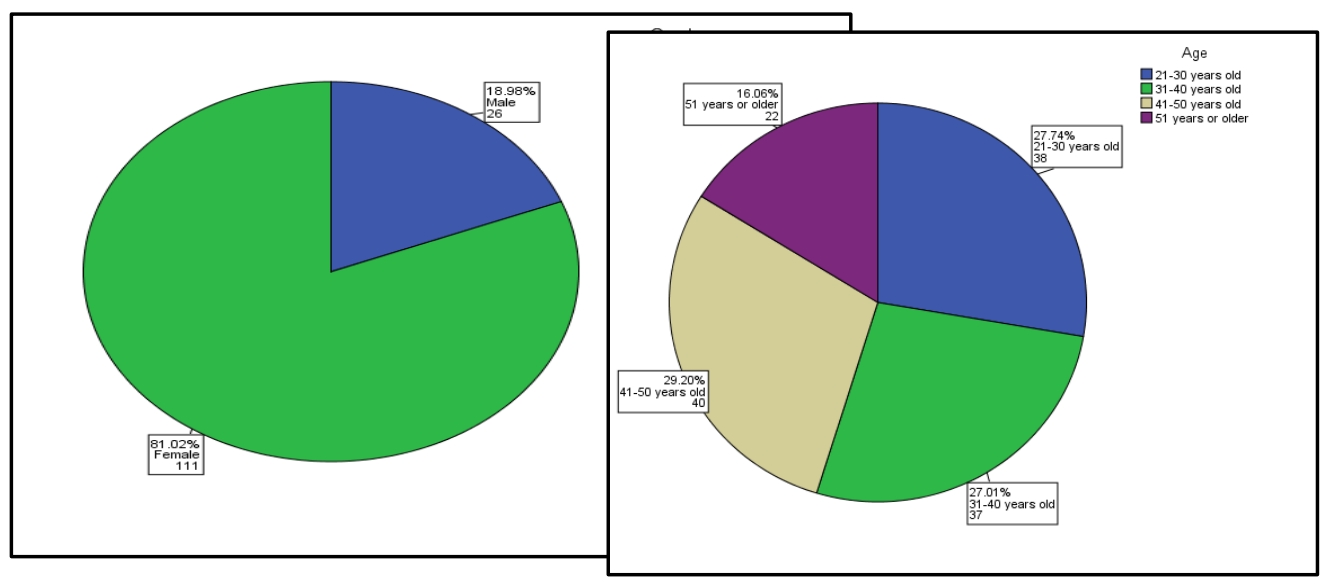

Education

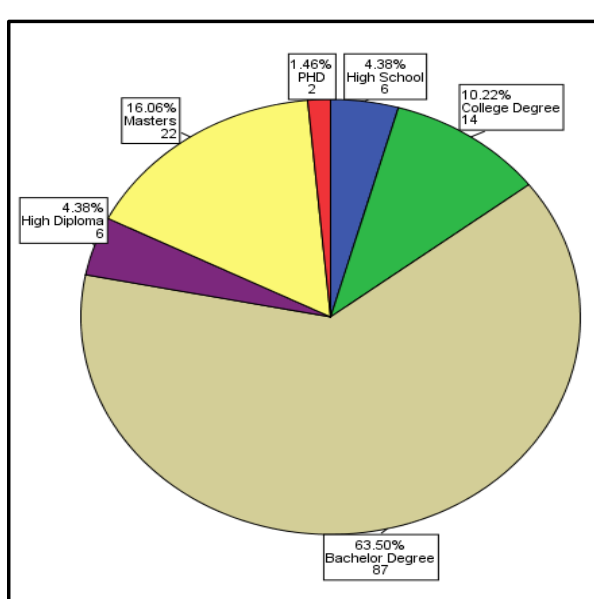

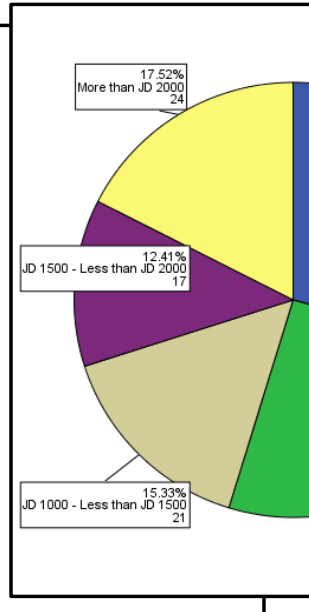

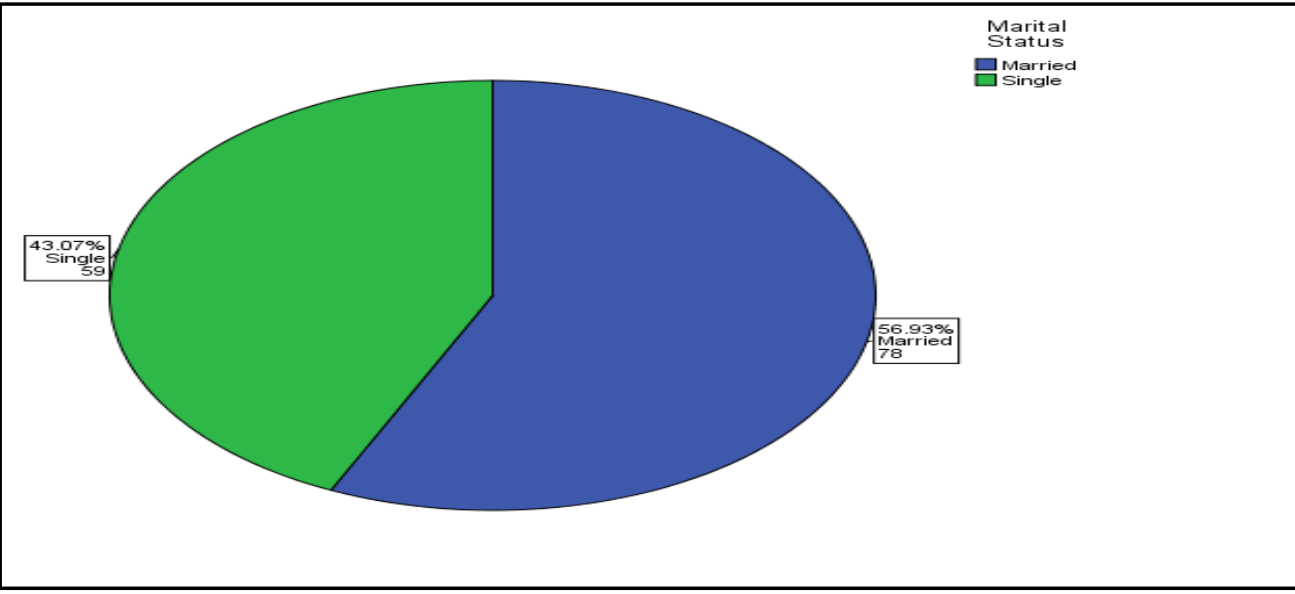


Data Analysis:

Levels of the variables

Table (3)

Levels of variables and T-test

\begin{tabular}{|l|c|c|c|c|c|}
\hline \multicolumn{1}{|c|}{ Variable } & Mean & Mode & SD & Skewness & T-test \\
\hline Commitment perspective & 3.09 & 3 & 0.692 & -0.266 & 52.356 \\
\hline Religion & 3.18 & 3 & 0.611 & -0.465 & 60.964 \\
\hline Financial Situation & 3.00 & 3 & 0.679 & -0.367 & 51.810 \\
\hline Laws & 3.10 & 3 & 0.547 & -0.284 & 66.436 \\
\hline Fostering & 3.13 & 3 & 0.717 & -0.080 & 51.038 \\
\hline Guardianship & 3.18 & 4 & 0.680 & -0.245 & 54.811 \\
\hline
\end{tabular}

\section{Research Hypotheses:}

\section{Main Hypothesis}

Ho: Community perspective, religion, financial situation and laws have no impact on the families'decision to offer fostering or seek guardianship to orphans at $(\alpha=0.05)$.

- A multiple regression analysis was conducted to test the above main hypothesis below and it was found that the model is significant $(\mathrm{F}=159.067$, $\mathrm{p}$-value $=0.0001<0.05)$ with $\mathrm{R}=0.735$ and $\mathrm{R}^{2}=0.541$.

- The community perspective, religion, financial situation and laws have a significant impact on families' decision to offer child fostering or seek guardianship to orphans $(\mathrm{t}=12.612$, $\mathrm{p}$-value $=0.0001<0.05)$ with a regression coefficient of 0.781 .

Table (4)

Community perspective, religion, financial situation and laws as predictors of fostering and guardianship

\begin{tabular}{|c|c|c|c|c|c|c|c|c|c|}
\hline Model & $\mathbf{R}$ & $\mathbf{R}^{2}$ & $\operatorname{Adj} R^{2}$ & $\mathbf{F}$ & Sig & $\boldsymbol{\beta}$ & Std. Error & $\mathbf{t}$ & Sig. \\
\hline (Constant) & \multirow{2}{*}{.735} & \multirow{2}{*}{.541} & \multirow{2}{*}{.538} & \multirow{2}{*}{159.067} & \multirow{2}{*}{.0001} & .721 & .194 & 3.722 & .000 \\
\hline Independent Factors & & & & & & .781 & .062 & 12.612 & .0001 \\
\hline
\end{tabular}

Ho1: Community Perspective has no impact on the families' decision to offer orphans fostering at ( $\alpha=0.05)$.

Table (5):

Community perspective as predictor of fostering

\begin{tabular}{|c|c|c|c|c|c|c|c|c|c|}
\hline Model & $\mathbf{R}$ & $\mathbf{R}^{2}$ & $\operatorname{Adj} R^{2}$ & $\mathbf{F}$ & Sig & $\beta$ & Std. Error & $\mathbf{t}$ & Sig. \\
\hline (Co & \multirow{2}{*}{0.293} & \multirow{2}{*}{0.086} & \multirow{2}{*}{0.079} & \multirow{2}{*}{12.654} & \multirow{2}{*}{0.001} & 2.187 & 0.270 & 8.090 & 0.000 \\
\hline Com & & & & & & 0.303 & 0.085 & 3.557 & 0.001 \\
\hline
\end{tabular}

From the above tables:

- The model is significant $(\mathrm{F}=12.654$, $\mathrm{p}$-value $=0.001<0.05)$ with $\mathrm{R}=0.293$ and $\mathrm{R}^{2}=0.086$.

- Community perspective has a significant effect on families' decision to offer child fostering ( $t=3.557, p$ value $=0.001<0.05$ ) with a regression coefficient of 0.303 .

Ho2: Religion has no impact on the families' decision to offer orphans fostering at ( $\alpha=0.05)$.

Table (6):

Religion as predictor of fostering

\begin{tabular}{|l|c|c|c|c|c|c|c|c|c|}
\hline \multicolumn{1}{|c|}{ Model } & $\mathbf{R}$ & $\mathbf{R}^{\mathbf{2}}$ & $\mathbf{A d j} \mathbf{R}^{\mathbf{2}}$ & $\mathbf{F}$ & Sig & $\boldsymbol{\beta}$ & Std. Error & $\mathbf{t}$ & Sig. \\
\cline { 1 - 6 } (Constant) & \multirow{2}{*}{0.126} & \multirow{2}{*}{0.016} & \multirow{2}{*}{0.009} & \multirow{2}{*}{2.182} & \multirow{2}{*}{0.142} & 2.655 & 0.325 & 8.180 & 0.000 \\
\cline { 1 - 5 } & & & & & & 0.148 & 0.100 & 1.477 & 0.142 \\
\hline
\end{tabular}

From the above tables:

- The model is not significant $(F=2.182$, $p$-value $=0.142>0.05)$ with $R=0.126$ and $\mathrm{R}^{2}=0.016$.

- Religion has no significant effect onfamilies' decision to offer child fostering $(\mathrm{t}=1.477$, $\mathrm{p}$-value $=0.142>0.05)$. 
Ho3: Financial Situation has no impact on the families' decision to offer orphan's fostering at ( $\alpha=0.05)$.

Table (7):

Financial situation as predictor of fostering

\begin{tabular}{|c|c|c|c|c|c|c|c|c|c|}
\hline Model & $\mathbf{R}$ & $\mathbf{R}^{2}$ & $\operatorname{Adj} R^{2}$ & $\mathbf{F}$ & Sig & $\beta$ & Std. Error & $\mathbf{t}$ & Sig. \\
\hline (Constant) & \multirow{2}{*}{0.285} & \multirow{2}{*}{0.081} & \multirow{2}{*}{0.075} & \multirow{2}{*}{11.962} & \multirow{2}{*}{0.001} & 2.221 & 0.268 & 8.277 & 0.000 \\
\hline Financial Situation & & & & & & 0.301 & 0.087 & 3.459 & 0.001 \\
\hline
\end{tabular}

From the above tables:

- The model is significant $(\mathrm{F}=11.962$, $\mathrm{p}$-value $=0.001<0.05)$ with $\mathrm{R}=0.285$ and $\mathrm{R}^{2}=0.081$.

- Financial situation has a significant effect on the families' decision to offer child fostering ( $\mathrm{t}=3.459$, $\mathrm{p}$ value $=0.001<0.05$ ) with a regression coefficient of 0.301 .

$\bullet$

Ho4: Laws has no impact on the families' decision to offer child fostering at ( $\alpha=0.05)$.

Table (8):

Laws as predictor of fostering

\begin{tabular}{|c|c|c|c|c|c|c|c|c|c|}
\hline \multicolumn{1}{|c|}{ Model } & $\mathbf{R}$ & $\mathbf{R}^{\mathbf{2}}$ & Adj R $^{\mathbf{2}}$ & $\mathbf{F}$ & Sig & $\boldsymbol{\beta}$ & Std. Error & $\mathbf{t}$ & Sig. \\
\cline { 1 - 5 } (Constant) & \multirow{2}{*}{0.345} & \multirow{2}{*}{0.119} & \multirow{2}{*}{0.112} & \multirow{2}{*}{18.192} & \multirow{2}{*}{0.0001} & 1.724 & 0.334 & 5.164 & 0.0001 \\
\cline { 1 - 5 } & & & & & & 0.452 & 0.106 & 4.265 & 0.0001 \\
\hline
\end{tabular}

From the above tables:

- The model is significant $(\mathrm{F}=18.192$, $\mathrm{p}$-value $=0.0001<0.05)$ with $\mathrm{R}=0.345$ and $\mathrm{R}^{2}=0.119$.

- Laws has a significant effect on the families' decision to offer child fostering $(\mathrm{t}=4.265$, $\mathrm{p}$-value $=0.0001<0.05)$ with a regression coefficient of 0.452 .

Ho5: Community Perspective has no impact on the families' decision to seek guardianship to a child at ( $\alpha=0.05)$.

Table (9):

Community perspective as predictor of guardianship

\begin{tabular}{|l|c|c|c|c|c|c|c|c|c|}
\hline \multicolumn{1}{|c|}{ Model } & $\mathbf{R}$ & $\mathbf{R}^{\mathbf{2}}$ & $\mathbf{A d j} \mathbf{R}^{\mathbf{2}}$ & $\mathbf{F}$ & $\mathbf{S i g}$ & $\boldsymbol{\beta}$ & Std. Error & $\mathbf{t}$ & Sig. \\
\hline (Constant) & \multirow{2}{*}{0.275} & \multirow{2}{*}{0.076} & \multirow{2}{*}{0.069} & \multirow{2}{*}{11.026} & \multirow{2}{*}{0.001} & 2.347 & 0.258 & 9.107 & 0.000 \\
\cline { 1 - 7 } & & & & & & 0.270 & 0.081 & 3.321 & 0.001 \\
\hline
\end{tabular}

From the above tables:

- The model is significant $(\mathrm{F}=11.026$, $\mathrm{p}$-value $=0.001<0.05)$ with $\mathrm{R}=0.275$ and $\mathrm{R}^{2}=0.076$.

- Community perspective has a significant effect on the families' decision to seek guardianship to a child ( $\mathrm{t}=3.321$, $\mathrm{p}$-value $=0.001<0.05$ ) with a regression coefficient of 0.270 .

Ho6: Religion has no impact on the families' decision to seek guardianship to a child at ( $\alpha=0.05)$.

Table (10):

Religion as predictor of guardianship

\begin{tabular}{|c|c|c|c|c|c|c|c|c|c|}
\hline Model & $\mathbf{R}$ & $\mathbf{R}^{2}$ & $\operatorname{Adj} R^{2}$ & $\mathbf{F}$ & Sig & $\beta$ & Std. Error & $\mathbf{t}$ & Sig. \\
\hline (Constant) & \multirow{2}{*}{0.167} & \multirow{2}{*}{0.028} & \multirow{2}{*}{0.021} & \multirow{2}{*}{3.869} & \multirow{2}{*}{0.051} & 2.592 & 0.306 & 8.474 & 0.000 \\
\hline Religion & & & & & & 0.186 & 0.094 & 1.967 & 0.051 \\
\hline
\end{tabular}

From the above tables:

- The model is not significant $(F=3.869$, $p$-value $=0.051>0.05)$ with $R=0.167$ and $\mathrm{R}^{2}=0.028$.

- Religion has no significant effect on the families' decision to seek guardianship to a child ( $\mathrm{t}=1.967, \mathrm{p}$ value $=0.051>0.05$ ) with a regression coefficient of 0.270 .

Ho7:Financial Situation has no impact on the families' decision to seek guardianship to a child at ( $\alpha=0.05)$.

Table (11):

Financial situation as predictor of guardianship

\begin{tabular}{|l|c|c|c|c|c|c|c|c|c|}
\hline \multicolumn{1}{|c|}{ Model } & $\mathbf{R}$ & $\mathbf{R}^{\mathbf{2}}$ & $\mathbf{A d j} \mathbf{R}^{\mathbf{2}}$ & $\mathbf{F}$ & $\mathbf{S i g}$ & $\boldsymbol{\beta}$ & Std. Error & $\mathbf{t}$ & Sig. \\
\cline { 1 - 7 } (Constant) & \multirow{2}{*}{0.274} & \multirow{2}{*}{0.075} & \multirow{2}{*}{0.068} & \multirow{2}{*}{10.922} & \multirow{2}{*}{0.001} & 2.359 & 0.255 & 9.244 & 0.000 \\
\cline { 1 - 6 } & & & & & & 0.274 & 0.083 & 3.305 & 0.001 \\
\hline
\end{tabular}

From the above tables: 
- The model is significant $(\mathrm{F}=10.922$, $\mathrm{p}$-value $=0.001<0.05)$ with $\mathrm{R}=0.274$ and $\mathrm{R}^{2}=0.075$.

- Financial situation has a significant effect on the families' decision to seek guardianship to a child ( $\mathrm{t}=3.305$, $\mathrm{p}$ value $=0.001<0.05$ ) with a regression coefficient of 0.274 .

Ho8: Laws has no impact on the families' decision to seek guardianship to a child at ( $\alpha=0.05)$.

Table (12):

Laws as predictor of guardianship

\begin{tabular}{|l|c|c|c|c|c|c|c|c|c|}
\hline \multicolumn{1}{|c|}{ Model } & $\mathbf{R}$ & $\mathbf{R}^{\mathbf{2}}$ & Adj R $^{\mathbf{2}}$ & $\mathbf{F}$ & Sig & $\boldsymbol{\beta}$ & Std. Error & $\mathbf{t}$ & Sig. \\
\cline { 1 - 5 } (Constant) & \multirow{2}{*}{0.298} & \multirow{2}{*}{0.089} & \multirow{2}{*}{0.082} & \multirow{2}{*}{13.109} & \multirow{2}{*}{0.0001} & 2.035 & 0.322 & 6.323 & 0.0001 \\
\cline { 1 - 5 } & & & & & & 0.370 & 0.102 & 3.621 & 0.0001 \\
\hline
\end{tabular}

From the above tables:

- The model is significant $(\mathrm{F}=13.109$, $\mathrm{p}$-value $=0.0001<0.05)$ with $\mathrm{R}=0.298$ and $\mathrm{R}^{2}=0.089$.

- Laws have significant effect on the families' decision to seek guardianship to a child ( $t=3.621$, $p$ value $=0.0001<0.05$ ) with a regression coefficient of 0.370 .

Ho9: There are no differences between community perspective, religion, financial situation and laws, and the families' decision to offer fostering or seek guardianship to a child when it comes to demographic and functional variables (Age, Gender, Religion, Level of Education, Monthly Income, and Marital Status) at ( $\alpha=0.05)$.

i. T-tests: (Gender, Religion, and Marital Status).

ii. ANAOVA: (Age, Level of Education, and Monthly Income).

\section{Gender:}

Two independent samples was conducted to test that there are no significant differences in the levels of community perspective, religion, financial situation and laws that can be attribute to gender:

Table (13):

T-test / Gender attribution to variables

\begin{tabular}{|l|c|c|c|c|c|}
\hline \multicolumn{1}{|c|}{ variable } & $\mathbf{t}$ & $\mathbf{d f}$ & Sig. (2-tailed) & Mean Difference & Std. Error Difference \\
\hline community perspective & -0.638 & 135 & 0.525 & -0.096 & 0.151 \\
\hline religion & -1.504 & 135 & 0.135 & -0.199 & 0.132 \\
\hline financial situation & -0.270 & 135 & 0.787 & -0.040 & 0.148 \\
\hline Laws & -1.194 & 135 & 0.235 & -0.142 & 0.119 \\
\hline Fostering & 0.372 & 135 & 0.711 & 0.058 & 0.157 \\
\hline guardianship & -1.121 & 135 & 0.264 & -0.166 & 0.148 \\
\hline
\end{tabular}

From the above table, there are no differences in the levels of community perspective, religion, financial situation, laws, fostering or guardianship that can be attribute to gender ( $\mathrm{p}$-value $>0.05$ ).

\section{Religion:}

Two independent samples was conducted to test that there are no significant differences in the levels of community perspective, religion, financial situation and laws that can be attribute to religion of the respondent:

Table (14):

T-test / Religion attribution to variables

\begin{tabular}{|l|c|c|c|c|c|}
\hline \multicolumn{1}{|c|}{ variable } & t & df & Sig. (2-tailed) & Mean Difference & Std. Error Difference \\
\hline community perspective & 0.342 & 135 & 0.733 & 0.069 & 0.202 \\
\hline religion & 0.882 & 135 & 0.379 & 0.157 & 0.178 \\
\hline financial situation & -0.838 & 135 & 0.404 & -0.166 & 0.198 \\
\hline Laws & 1.974 & 135 & 0.051 & 0.311 & 0.158 \\
\hline Fostering & -0.655 & 135 & 0.514 & -0.137 & 0.209 \\
\hline guardianship & -0.697 & 135 & 0.487 & -0.138 & 0.198 \\
\hline
\end{tabular}


From the above table, there are no differences in the levels of community perspective, religion, financial situation and laws, fostering or guardianship that can be attribute to religion of the respondents ( $\mathrm{p}$-value $>0.05$ ).

\section{Marital Status:}

Two independent samples was conducted to test that there are no significant differences in the levels of community perspective, religion, financial situation and laws that can be attribute to marital status:

Table (15):

T-test / Marital Status attribution to variables

\begin{tabular}{|l|c|c|c|c|c|}
\hline \multicolumn{1}{|c|}{ Variable } & t & df & Sig. (2-tailed) & Mean Difference & Std. Error Difference \\
\hline community perspective & 2.415 & 135 & 0.017 & 0.283 & 0.117 \\
\hline religion & 0.609 & 135 & 0.544 & 0.064 & 0.106 \\
\hline financial situation & -1.477 & 135 & 0.142 & -0.172 & 0.117 \\
\hline Laws & 1.435 & 135 & 0.153 & 0.135 & 0.094 \\
\hline Fostering & -0.377 & 135 & 0.707 & -0.047 & 0.124 \\
\hline guardianship & -0.502 & 135 & 0.616 & -0.059 & 0.118 \\
\hline
\end{tabular}

From the above table, there are significant differences in the levels of community perspective than can be attributed to marital status, married tends to have higher scores (mean for married=3.22 while mean for single $=2.93$ ). No significant differences in the levels of other variables that can be attributed to marital status.

\section{Age:}

An analysis of variance was conducted to test that there are no significant differences in the levels of community perspective, religion, financial situation and laws that can be attribute to age.

Table (16):

ANOVA / Age attribution to variables

\begin{tabular}{|l|l|c|c|c|c|c|}
\hline \multicolumn{1}{|c}{ variable } & source of variation & Sum of Squares & df & Mean Square & F & Sig. \\
\hline \multirow{4}{*}{ community perspective } & Between Groups & 2.640 & 3 & 0.880 & 1.875 & 0.137 \\
\cline { 2 - 7 } & Within Groups & 62.404 & 133 & 0.469 & & \\
\hline & Total & 65.044 & 136 & & & \\
\hline \multirow{4}{*}{ feligion } & Between Groups & 1.682 & 3 & 0.561 & 1.521 & 0.212 \\
\hline & Within Groups & 49.034 & 133 & 0.369 & & \\
\hline & Total & 50.716 & 136 & & & \\
\hline \multirow{4}{*}{ laws } & Between Groups & 0.076 & 3 & 0.025 & 0.054 & 0.984 \\
\hline & Within Groups & 62.547 & 133 & 0.470 & & \\
\cline { 2 - 8 } & Total & 62.623 & 136 & & & \\
\hline \multirow{5}{*}{ fostering } & Between Groups & 0.470 & 3 & 0.157 & 0.519 & 0.670 \\
\hline & Within Groups & 40.155 & 133 & 0.302 & & \\
\hline & Total & 40.625 & 136 & & & \\
\hline \multirow{5}{*}{ guardianship } & Between Groups & 0.132 & 3 & 0.044 & 0.084 & 0.969 \\
\hline & Within Groups & 69.759 & 133 & 0.525 & & \\
\hline & Total & 69.891 & 136 & & & \\
\hline & Between Groups & 0.771 & 3 & 0.257 & 0.551 & 0.648 \\
\hline & Within Groups & 62.041 & 133 & 0.466 & & \\
\hline & Total & 62.813 & 136 & & & \\
\hline
\end{tabular}

From the above table, there are no significant differences in the level of community perspective, religion, financial situation, laws, fostering or guardianship that can be attributed to age (p-value>0.05). 


\section{Level of Education:}

An analysis of variance was conducted to test that there are no significant differences in the levels of community perspective, religion, financial situation and laws that can be attribute to levels of education.

Table (17):

ANOVA / Levels of education attribution to variables

\begin{tabular}{|c|c|c|c|c|c|c|}
\hline variable & source of variation & Sum of Squares & df & Mean Square & $\mathbf{F}$ & Sig. \\
\hline \multirow{3}{*}{ community perspective } & Between Groups & 7.718 & 5 & 1.544 & 3.528 & 0.005 \\
\hline & Within Groups & 57.326 & 131 & 0.438 & & \\
\hline & Total & 65.044 & 136 & & & \\
\hline \multirow{3}{*}{ religion } & Between Groups & 1.030 & 5 & 0.206 & 0.543 & 0.743 \\
\hline & Within Groups & 49.686 & 131 & 0.379 & & \\
\hline & Total & 50.716 & 136 & & & \\
\hline \multirow{3}{*}{ financial situation } & Between Groups & 1.688 & 5 & 0.338 & 0.726 & 0.605 \\
\hline & Within Groups & 60.935 & 131 & 0.465 & & \\
\hline & Total & 62.623 & 136 & & & \\
\hline \multirow{3}{*}{ laws } & Between Groups & 2.603 & 5 & 0.521 & 1.794 & 0.118 \\
\hline & Within Groups & 38.022 & 131 & 0.290 & & \\
\hline & Total & 40.625 & 136 & & & \\
\hline \multirow{3}{*}{ fostering } & Between Groups & 1.760 & 5 & 0.352 & 0.677 & 0.642 \\
\hline & Within Groups & 68.131 & 131 & 0.520 & & \\
\hline & Total & 69.891 & 136 & & & \\
\hline \multirow{3}{*}{ guardianship } & Between Groups & 0.432 & 5 & 0.086 & 0.182 & 0.969 \\
\hline & Within Groups & 62.381 & 131 & 0.476 & & \\
\hline & Total & 62.813 & 136 & & & \\
\hline
\end{tabular}

From the above table, there are significant differences in the levels of community perspective that can be attributed to the levels of education. (LSD test showed that Bachelor and Master Groups tends to have lower scores compared to high school group.)

\section{Monthly Income:}

An analysis of variance was conducted to test that there are no significant differences in the levels of community perspective, religion, financial situation and laws that can be attribute to income

Table (18):

ANOVA / Monthly income attribution to variables

\begin{tabular}{|l|l|c|c|c|c|c|}
\hline \multicolumn{1}{|c}{ Variable } & Source of Variation & Sum of Squares & df & Mean Square & F & Sig. \\
\hline \multirow{4}{*}{ community perspective } & Between Groups & 5.022 & 4 & 1.256 & 2.761 & 0.030 \\
\cline { 2 - 7 } & Within Groups & 60.022 & 132 & 0.455 & & \\
\cline { 2 - 7 } & Total & 65.044 & 136 & & & \\
\hline \multirow{4}{*}{ religion } & Between Groups & 1.891 & 4 & 0.473 & 1.278 & 0.282 \\
\cline { 2 - 8 } & Within Groups & 48.825 & 132 & 0.370 & & \\
\cline { 2 - 8 } & Total & 50.716 & 136 & & & \\
\hline \multirow{4}{*}{ laws } & Between Groups & 0.947 & 4 & 0.237 & 0.507 & 0.731 \\
\cline { 2 - 7 } & Within Groups & 61.676 & 132 & 0.467 & & \\
\cline { 2 - 7 } & Total & 62.623 & 136 & & & \\
\hline & Between Groups & 0.528 & 4 & 0.132 & 0.434 & 0.784 \\
\cline { 2 - 7 } & Within Groups & 40.097 & 132 & 0.304 & & \\
\cline { 2 - 7 } & Total & 40.625 & 136 & & & \\
\hline
\end{tabular}




\begin{tabular}{|l|l|c|c|c|c|c|}
\multirow{5}{*}{ fostering } & Between Groups & 1.234 & 4 & 0.309 & 0.593 & 0.668 \\
\cline { 2 - 7 } & Within Groups & 68.656 & 132 & 0.520 & & \\
\cline { 2 - 7 } guardianship & Total & 69.891 & 136 & & & \\
\hline & Between Groups & 0.370 & 4 & 0.093 & 0.196 & 0.940 \\
\hline & Within Groups & 62.443 & 132 & 0.473 & & \\
\cline { 2 - 7 } & Total & 62.813 & 136 & & & \\
\hline
\end{tabular}

From the above table, there are significant differences in the levels of community perspective that can be attributed to the levels of income. LSD test showed that respondent

\section{Conclusion and Recommendations:}

\section{Conclusions:}

- The Community perspective, religion, financial situation and laws have a significant effect on families' decision to offer child fostering or seek guardianship to a child ( $\mathrm{p}$-value $=0.0001<0.05$ ).

$>$ Since the p-value $(0.0001)$ is less than the alpha $(0.05)$, we reject the null hypothesis that the "Community perspective, religion, financial situation and laws have no impact on the families' decision to offer fostering or seek guardianship to a child".

- Community perspective has a significant effect on the families' decision to offer child fostering (pvalue $=0.001<0.05)$.

$>$ Since the p-value (0.0001) is less than the alpha (0.05), we reject the null hypothesis that the "Community Perspective has no impact on the families' decision to offer child fostering".

- Religion has no significant effect on the families' decision to offer child fostering (p-value $=0.142>0.05$ ).

$>$ Since the p-value (0.142) is more than alpha (0.05), we accept the null hypothesis that the "Religion has no impact on the families' decision to offer child fostering".

- Financial situation has a significant effect on the families' decision to offer child fostering ( $\mathrm{p}$-value $=0.001<0.05$ ).

$>$ Since the p-value (0.0001) is less than the alpha (0.05), we reject the null hypothesis that the "Financial Situation has no impact on the families' decision to offer child fostering".

- Laws has a significant effect on the families' decision to offer child fostering ( $\mathrm{p}$-value $=0.0001<0.05$ ).

$>$ Since the p-value (0.0001) is less than the alpha (0.05), we reject the null hypothesis that the "Laws has no impact on the families' decision to offer child fostering".

- Community perspective has a significant effect on the families' decision to seek guardianship to a child (pvalue $=0.001<0.05)$.

$>$ Since the p-value (0.001) is less than the alpha (0.05), we reject the null hypothesis that the "Community Perspective has no impact on the families' decision to seek guardianship to a child".

- Religion has no significant effect on the families' decision to seek guardianship to a child ( $\mathrm{p}$-value $=0.051>0.05$ ).

$>$ Since the p-value (0.051) is more than the alpha (0.05), we accept the null hypothesis that the "Religion has no impact on the families' decision to seek guardianship to a child".

- Financial situation has a significant effect on the families' decision to seek guardianship to a child (pvalue $=0.001<0.05)$.

$>$ Since the p-value (0.001) is less than the alpha (0.05), we reject the null hypothesis that the "Financial Situation has no impact on the families' decision to seek guardianship to a child".

- Laws have significant effect on the families' decision to seek guardianship to a child ( $\mathrm{p}$-value $=0.0001<0.05$ ).

$>$ Since the p-value (0.0001) is less than the alpha (0.05), we reject the null hypothesis that the "Laws has no impact on the families' decision to seek guardianship to a child".

- There are no differences between community perspective, religion, financial situation and laws, and the families' decision to offer fostering or seek guardianship to a child when it comes to demographic and functional variables (Age, Gender, Religion, Level of Education, Monthly Income, and Marital Status).

$>$ There are no differences in the levels of community perspective, religion, financial situation, laws, fostering or guardianship that can be attribute to gender, religion, and age.

$>$ There are significant differences in the levels of community perspective that can be attributed to marital status, levels of education, and levels of incomes. No significant differences in the levels of the other variables. 


\section{Recommendations}

- Ensure that religion representatives (Mosques and churches), puts more emphasis on explaining that fostering and guardianship as legal alternatives of adoption. Furthermore, they are highly encouraged acts by all religions in an effort to encourage families to participate in the program to provide the abandoned children a decent life and potentially move into a caring and loving family as one of their own.

- Future researchers need toexceed the limitations in the literature of the previous research related to adoption alternatives (fostering and guardianship). The future research literature should concentrate on how triad members cope with the stressors of fostering and guardians family life.

\section{References}

- Adkins, L, et al. (1998), "Handbook to Life in Ancient Rome", Oxford University Press, New York, USA.

- Bargach, J. (2002), "Orphans of Islam: Family, Abandonment, and Secret Adoption in Morocco", Rowman \& Littlefield Publishers, Lanham, Maryland.

- Eugena, B. (2015), “Adoption in ancient times”, European Sciences Review Scientific Journal, Issue No. 9-10, PP. $172-173$.

- Figueras, A. (2016), "Breaking the Adoption Taboo in Dubai", The Islamic Monthly, Issue Winter 2015/2016, PP. 5.

- Fisher (2015),

- Grossman, R. (2018), "The Orphan Train: A Noble Idea That Went off the Rails", Chicago Tribune, p.3.

- Hornblower, S, et al. (2014), "The Oxford Companion to Classical Civilization”, Oxford University Press, $2^{\text {nd }}$ Edition, Oxford, UK.

- http://www.mosd.gov.jo/UI/Arabic/ShowContent.aspx?ContentId=112

- http://www.mosd.gov.jo/UI/Arabic/ShowContent.aspx?ContentId=369

- https://www.vocabulary.com/dictionary/adoption

- Kirk, H. (1964), "A Theory of Adoption and Mental Health", The Free Press of Glencoe, Vol. 43, Issue 1, PP. 120125.

- Pollack, D. (2003), "Classical Religious Perspectives of Adoption Law”, Notre Dame L. Rev., Vol. 79, Issue 2, PP 696

- Raisch, M. (2017), "Religious Legal Systems in Comparative Law: A Guide to Introductory Research", GlobaLex, [online] Nyulawglobal.org. Available at: https://www.nyulawglobal.org/globalex/Religious_Legal_Systems1.html

- UNICEF (2007), "Implementation Handbook for the Convention on the Rights of the Child", [online] Available at: https://www.refworld.org/pdfid/585150624.pdf

- UNICEF/UNAIDS (1999), "Children Orphaned by AIDS. Front-Line Responses from Eastern and Southern Africa", UNICEF Division of Communication, New York, USA.

- Yeats, j. (2006), “The Biblical Model of Adoption”, Southwestern Journal of Theology, Texas, Vol. 9, No. 5, pp 34-50. 